\title{
TANGGUNG GUGAT PEJABAT TATA USAHA NEGARA DALAM BENTUK PEMBATALAN SERTIPIKAT HAK ATAS TANAH
}

\author{
Fani Martiawan Kumara Putra \\ Fakultas Hukum Universitas Wijaya Kusuma Surabaya \\ Email : fanimartiawan@gmail.com
}

\begin{abstract}
The ownership of land rights, may be proven by the issuance of land rights certificate which is an authority of the Badan Pertanahan Nasional $(B P N)$. Land rights may be used as a guarantee for credit payment that based on the security of law regulation, and related to the land as the object, it have to use Hak Tanggungan as the security agency. Land rights which are used as a guarantee, wheter it is hak milik, hak guna usaha or hak guna bangunan are fully depended on the related land rights certificate. If the land rights certificate flawed and must be cancelled, then it will rise some problems, such as the authority's party have to take responsibility, and of course the condition of Hak Tanggungan will be affected.
\end{abstract}

Keywords : Cancellation, Certificate, Guarantee

\begin{abstract}
ABSTRAK
Kepemilikan hak atas tanah, dapat dibuktikan dengan dikeluarkannya sertipikat hak atas tanah yang merupakan kewenangan Badan Pertanahan Nasional (BPN). Hak atas tanah dapat dijadikan jaminan pelunasan hutang sesuai dengan pengaturan hukum jaminan dalam hal ini lembaganya jaminannya adalah Hak Tanggungan. Hak atas tanah yang dijaminkan, baik itu hak milik, hak guna bangunan atau hak guna usaha sangat bergantung pada sertipikat hak atas tanah yang bersangkutan. Bilamana suatu saat ternyata sertipikat hak atas tanah yang sedang dijaminkan itu cacat dan harus dibatalkan, maka muncul tanggung gugat pejabat yang berwenang dan permasalahan terkait status dari jaminan Hak Tanggungan tersebut.
\end{abstract}

Kata kunci: Pembatalan, Sertipikat, Jaminan

\section{PENDAHULUAN}

Dalam perkembangannya penting yang dihadapi oleh

diantara masalah-masalah negara sedang berkembang

Fani Martiawan, Tanggung Gugat Pejabat Tata Usaha Negara Dalam Bentuk Pembatalan Sertipikat Hak Atas Tanah 
Supremasi Hukum Jurnal Penelitian Hukum

p-ISSN: 1693-766X ; e-ISSN: 2579-4663, Vol. 26, No. 2, Agustus 2017

seperti Indonesia, disamping pembangunan ekonomi dan sosial juga pembangunan di bidang hukum. Persoalan psikologis-politis untuk melepaskan diri dari ikatan masa lampau yang berbau kolonial, juga persoalan bahwa seringkali banyak hukum dari masa lampau sudah tidak cocok lagi dengan kebutuhan masyarakat yang telah mengalami perubahan, dengan berpegang pada pandangan bahwa hukum adalah refleksi dari keadaan masyarakat pada suatu masa tertentu, maka akan sulitlah untuk mempertahankan hukum yang lama dalam suasana kehidupan baru. Oleh karena itu hukum baru harus dapat memberikan tanggapan yang tepat kepada kebutuhan masyarakat pada zaman yang telah berubah.

Hukum sebagai suatu system yang merupakan tatanan kesatuan yang utuh ${ }^{1}$,

Sudikno Mertokusumo, Mengenal Hukum, (Suatu Pengantar), Yogyakarta, Liberty, Edisi Kelima, Cetakan Keempat, 2008, hlm. 122. menghendaki agar komponen yang menjadi bagian didalamnya selalu harmonis, tidak terjadi kontroversi antara aturan perundangan yang satu dengan lainnya. Konsistensi wajib dijaga agar kepastian hukum yang dicita-citakan masyarakat dapat terlaksana, dan keadilan selalu terjamin. Apabila semua itu terwujud, akan melahirkan tertib hukum yang bagus, dan masyarakat menjadi aman, damai dan tidak terjadi konflik. Demikian juga kekuatan ekonomi nasional yang selalu dilegalisasi oleh hukum, baik yang berskala kecil, menengah, ataupun yang besar akan mampu bersinergi dalam rangka menstabilkan pembangunan berkelanjutan.

Muchammad Zaidun mengemukakan bahwa pada Negara yang sedang dalam masa transisi menuju demokrasi dan menuju ke Negara yang menganut prinsip "Rule of Law"2,

2 Henry Chambell Black, Bryan A. Garner, Black's Law Dictionary, 9th Edition, 2010, hlm. 1448. Diterjemahkan bahwa Rule of Fani Martiawan, Tanggung Gugat Pejabat Tata Usaha Negara Dalam Bentuk Pembatalan Sertipikat Hak Atas Tanah 
Supremasi Hukum Jurnal Penelitian Hukum

p-ISSN: 1693-766X ; e-ISSN: 2579-4663, Vol. 26, No. 2, Agustus 2017

hukum yang berlaku belum sepenuhnya mencerminkan rasa keadilan masyarakat. Hukum tersebut belum aspiratif (belum sepenuhnya dapat menyuarakan dan mencerminkan nilai-nilai yang hidup di masyarakat), bahkan sering dituding sebagai suatu hukum yang mencerminkan kehendak dan kepentingan penguasa yang tidak jarang mengabaikan rasa keadilan masyarakat. ${ }^{3}$ Lebih jauh Muchammad Zaidun mengatakan bahwa untuk mencapai suatu suasana kehidupan masyarakat hukum yang mampu menegakkan kepastian hukum dan sekaligus mencerminkan rasa keadilan masyarakat maka diperlukan beberapa faktor, yaitu: adanya suatu perangkat hukum yang demokratis, (aspiratif), adanya struktur birokrasi kelembagaan

Law is the doctrine that every person is subject to the ordinary law within the jurisdiction.

${ }^{3}$ Muchammad Zaidun, Tantangan Dan Kendala Kepastian Hukum Di Indonesia, Kapita Selekta Penegakan Hukum di Indonesia, Jakarta: Prestasi Pustaka, 2006, hlm. 119-120.

${ }^{4} \mathrm{Ibid}, \mathrm{hlm} .120$.
Usaha Negara Dalam Bentuk

Fani Martiawan, Tanggung Gugat Pejabat Tata Usaha Negara Dalam Bentuk Pembatalan Sertipikat Hak Atas Tanah

hukum yang efisien dan efektif serta transparan dan akuntabel, adanya aparat hukum dan profesi hukum yang profesional, dan memiliki integritas moral yang tinggi, adanya budaya menghormati, taat dan menjunjung tinggi nilai-nilai hukum dan HAM (menegakkan supremasi hukum/rule of law). ${ }^{4}$

Dalam rangka memelihara kesinambungan pembangunan ekonomi dan perdagangan di Negara manapun khususnya di Indonesia, diperlukan keseimbangan dan keserasian diantara orang-perorangan dengan pemerintah. Salah satu bentuk interaksi antara perseorangan dengan pemerintah adalah bentuk izin dalam bidang pertanahan. Tanah dan sertifikat merupakan dua hal yang tidak bisa dipisahkan dan saling melengkapi satu sama lain. Sertifikat merupakan alat bukti kepemilikan yang sah dan kuat mengenai hak atas tanah. Suatu pengakuan dan penegasan dari Negara terhadap 
Supremasi Hukum Jurnal Penelitian Hukum

p-ISSN: 1693-766X ; e-ISSN: 2579-4663, Vol. 26, No. 2, Agustus 2017

penguasaan tanah secara perorangan atau bersama atau badan hukum yang namanya tertulis di dalam sertifikat dan sekaligus menjelaskan lokasi, gambar situasi, ukuran dan batas-batas bidang tanah tersebut. Untuk memperoleh sertifikat dibutuhkan pendaftaran atas obyek tanah oleh pemiliknya.

Kegiatan pendaftaran tanah dilakukan oleh pemerintah dalam hal ini Badan Pertanahan Nasional berdasarkan Pasal 19 ayat (2) Undang-Undang Nomor 5 Tahun 1960 Tentang Peraturan Dasar Pokok-Pokok Agraria (UUPA), meliputi:

1. Pengukuran perpetaan dan pembukuan tanah

2. Pendaftaran hak-hak atas tanah dan peralihan hak-hak tersebut

3. Pemberian surat-surat tanda bukti hak, yang berlaku sebagai alat pembuktian yang kuat.

Ketentuan Pasal 19 ayat (2) huruf (c) ini dituangkan pula dalam Pasal 23 ayat (2), Pasal 32 ayat (2) dan Pasal 38 ayat (2) UUPA, selain itu dalam Pasal 32 ayat (1) Peraturan Pemerintah No. 24 Tahun 1997 Tentang Pendaftaran Tanah (PP Pendaftaran Tanah) juga menyatakan bahwa pendaftaran tanah menghasilkan surat tanda bukti yang berlaku sebagai alat pembuktian yang kuat.

Berdasarkan Pasal 32 ayat (1) PP Pendaftaran Tanah, sistem publikasi pendaftaran tanah menganut sistem publikasi negatif, yaitu sertipikat hanya merupakan surat tanda bukti hak yang bersifat kuat dan bukan merupakan surat tanda bukti hak yang bersifat mutlak. Di dalam sistem publikasi negatif Negara tidak menjamin kebenaran data yang disajikan. Tetapi walaupun demikian tidaklah dimaksudkan untuk menggunakan sistem publikasi negatif secara murni. Hal tersebut tampak dari pernyataan dalam Pasal 19 ayat (2) huruf c UUPA, bahwa surat tanda bukti hak yang diterbitkan berlaku 
Supremasi Hukum Jurnal Penelitian Hukum

p-ISSN: 1693-766X ; e-ISSN: 2579-4663, Vol. 26, No. 2, Agustus 2017

sebagai alat bukti yang kuat dan dalam Pasal 23, 32, dan 38 UUPA bahwa pendaftaran berbagai peristiwa hukum merupakan alat pembuktian yang kuat. Hal ini berarti bahwa data fisik dan data yuridis yang tercantum dalam sertipikat mempunyai kekuatan hukum dan harus diterima oleh hakim sebagai keterangan yang benar selama dan sepanjang tidak ada bukti lain yang membuktikan sebaliknya. Dengan demikian, pengadilanlah yang berwenang memutuskan alat bukti mana yang benar dan juga apabila terbukti sertipikat itu tidak benar, maka diadakan perubahan dan pembetulan sebagaimana mestinya.

Mencermati ketentuan

Pasal 32 ayat (1) PP Pendaftaran Tanah tersebut terdapat kelemahan, yaitu Negara tidak menjamin kebenaran data fisik dan data yuridis yang disajikan dan tidak adanya jaminan bagi pemilik sertipikat dikarenakan sewaktu-waktu akan mendapatkan gugatan dari pihak lain yang merasa dirugikan atas terbitnya sertipikat. Hal tersebut dilengkapi dengan Pasal 32 ayat (2) yang menyatakan: Dalam hal atas suatu bidang tanah sudah diterbitkan sertipikat secara sah atas nama orang atau badan hukum yang memperoleh tanah tersebut dengan itikad baik dansecara nyata menguasainya, maka pihak lain yang merasa mempunyai hak atas tanah itu tidak dapat lagi menuntut pelaksanaan hak tersebut apabila dalam kurun waktu 5 (lima) tahun sejak diterbitkannya sertipikat itu tidak mengajukan keberatan secara tertulis kepada pemegang sertipikat dan Kepala Kantor Pertanahan yang bersangkutan ataupun tidak mengajukan gugatan ke pengadilan mengenai penguasaan tanah atau penerbitan sertipikat tersebut.

Ketentuan diatas mengandung empat unsur yaitu (1). Sertipikat diterbitkan secara sah atas nama orang atau badan hukum; (2). Tanah diperoleh dengan itikad baik; (3). Tanah

Fani Martiawan, Tanggung Gugat Pejabat Tata Usaha Negara Dalam Bentuk Pembatalan Sertipikat Hak Atas Tanah 
Supremasi Hukum Jurnal Penelitian Hukum

p-ISSN: 1693-766X ; e-ISSN: 2579-4663, Vol. 26, No. 2, Agustus 2017

dikuasai secara nyata; (4).

antara aanvullend recht dengan

Dalam kurun waktu 5 (lima) dwingend recht, pertama, perlu tahun sejak diterbitkannya diketahui hakikat dari peraturan sertipikat itu tidak ada yang mengajukan keberatan secara tertulis kepada pemegang seripikat dan Kepala Kantor Pertanahan Kabupaten/Kota setempat ataupun ke pengadilan, mengenai penguasaan tanah atau penerbitan sertipikat. Keempat unsur ini haruslah kumulatif dipenuhi. Oleh karena itu bila di kemudian hari ada pihak yang menggugat karena merasa berhak dan keberatan atas tanah tersebut, maka pihak tersebut dalam mengajukan gugatan harus dapat membuktikan bahwa keempat unsur itu ada dalam pihak dan obyek yang mau digugat. Setelah dapat dibuktikan, maka sertifikat itu bersifat publikasi negatif sehingga dapat dibatalkan. Hal ini dikarenakan aturan tersebut bersifat dwingend recht. Herlien Budiono menganjurkan jika ingin mendalami arti perbedaan yang bersifat mengatur dan yang bersifat memaksa, dan kedua, perlu mengetahui apa yang mendasari prinsip atau merupakan asasnya. ${ }^{5}$

Di Indonesia bila terjadi sengketa pertanahan terutama sengketa secara vertikal antara masyarakat dengan pemerintah, maka kebijakan atau peraturan yang dibuat oleh pemerintah merupakan faktor yang terpenting dalam penyelesaian sengketa. Dalam sengketa pertanahan yang berhubungan dengan bidang administratif, pada dasarnya salah satu pihak dapat membawa kasusnya kepada Pengadilan Tata Usaha Negara (PTUN). Dalam hal ini PTUN dapat mengeluarkan Keputusan Tata Usaha Negara (KTUN) yang tindakannya berupa pencabutan atau pembatalan sertifikat hak atas tanah.

5 Herlien Budiono, Kumpulan Tulisan Hukum Perdata Di Bidang Kenotariatan, Buku Kedua, Citra AdityaBakti, Bandung, 2010, hlm. 125.

Fani Martiawan, Tanggung Gugat Pejabat Tata Usaha Negara Dalam Bentuk Pembatalan Sertipikat Hak Atas Tanah 
Supremasi Hukum Jurnal Penelitian Hukum

p-ISSN: 1693-766X ; e-ISSN: 2579-4663, Vol. 26, No. 2, Agustus 2017

Sengketa hak atas tanah yang berujung kepada pembatalan atau pencabutan hak atas tanah juga membawa implikasi status tanah yang terkait dengan lembaga jaminan. Sebagaimana diketahui bahwa tanah sebagai benda tidak bergerak atau tetap dapat menjadi obyek jaminan Hak Tanggungan. Dalam perjanjian kredit, berdasarkan peraturan perundang-undangan Pasal 1131 jo. 1132 Burgerlijk Wetboek (BW) atau Kitab Undang-Undang Hukum Perdata (KUHPerdata), telah diberikan pengaman kepada kreditor dalam menyalurkan kredit kepada pihak debitor, yakni dengan adanya jaminan umum yang menentukan bahwa semua harta kekayaan (kebendaan) debitor baik bergerak maupun tidak bergerak, yang sudah ada maupun yang akan ada menjadi jaminan atas seluruh perikatannya dengan kreditor. Apabila terjadi wanprestasi maka seluruh harta benda debitor dijual lelang dan dibagi-bagi rata menurut besar kecilnya piutang masing-masing kreditor.

Tanah sebagai benda tidak bergerak dapat menjadi obyek jaminan berdasarkan 1132 BW. Mengacu pada Undang-Undang No. 5 Tahun 1960 tentang Peraturan Dasar Pokok-Pokok Agraria (UUPA), tanah sebagai obyek jaminan dikuasasi dengan hak tanggungan diatur UndangUndang No. 4 Tahun 1996 tentang Hak Tanggungan Atas Tanah Beserta Benda-Benda Yang Berkaitan Dengan Tanah (UUHT. Pasal 1 ayat (1) UUHT, yang menyebutkan bahwa: "Hak Tanggungan adalah hak jaminan yang dibebankan pada hak atas tanah sebagaimana dimaksud dalam UUPA, berikut atau tidak berikut benda-benda lain yang merupakan satu kesatuan dengan tanah itu, untuk pelunasan utang tertentu, yang memberikan kedudukan yang diutamakan kepada kreditor tertentu terhadap kreditorkreditor yang lain.

Berdasarkan uraian tersebut yang menjadi persoalan

Fani Martiawan, Tanggung Gugat Pejabat Tata Usaha Negara Dalam Bentuk Pembatalan Sertipikat Hak Atas Tanah 
Supremasi Hukum Jurnal Penelitian Hukum

p-ISSN: 1693-766X ; e-ISSN: 2579-4663, Vol. 26, No. 2, Agustus 2017

adalah apabila penyelesaian sengketa pertanahan atas dasar cacat administrasi oleh PTUN berkaitan dengan hak atas tanah dalam keadaan dijaminkan dengan hak tanggungan. Oleh karena itu permasalahan yang dikaji dalam tulisan ini adalah bagaimana implikasi KTUN yang berujung pencabutan atau pembatalan hak terhadap obyek sengketa yang sedang dijaminkan dengan jaminan hak tanggungan.

\section{PEMBAHASAN}

\section{Pendaftaran Hak Atas Tanah}

Pasal 1 angka (1) PP No. 24 Tahun 1997 menyebutkan bahwa Pendaftaran tanah adalah rangkaian kegiatan yang dilakukan oleh pemerintah secara terus-menerus, berkesinambungan dan teratur, meliputi pengumpulan, pengolahan, pembukuan, dan penyajian serta pemeliharaan data fisik dan data yuridis, dalam bentuk peta dan daftar, mengenai bidang-bidang tanah dan satuan-satuan rumah susun, termasuk pemberian surat tanda bukti hak nya bagi bidang-bidang tanah yang sudah ada hak-nya dan hak milik atas satuan rumah susun serta hakhak tertentu yang membebaninya. Kata kunci pendaftran tanah disini adalah suatu rangkaian kegiatan, terusmenerus, dan teratur. Hal ini merupakan tugas Negara yang dilaksanakan oleh Badan Pertanahan Nasional bagi kepentingan rakyat, dalam rangka memberikan jaminan kepastian hukum dibidang pertanahan. Berdasarkan Pasal 2 dan Penjelasannya dilakukan dengan asas sederhana, aman, terjangkau, mutakhir dan terbuka.

Obyek pendaftaran tanah diatur dalam Pasal 9 PP Pendaftaran Tanah, yang meliputi: tanah dengan hak milik, hak guna usaha, hak guna bangunan dan hak pakai; Tanah hak pengelolaan;Tanah wakaf; Hak milik atas satuan rumah susun; Hak Tanggungan; Tanah Negara. Dalam hal tanah Negara 
Supremasi Hukum Jurnal Penelitian Hukum

p-ISSN: 1693-766X ; e-ISSN: 2579-4663, Vol. 26, No. 2, Agustus 2017

sebagai obyek pendaftaran tanah sebagaimana dimaksud pada ayat (1) huruf (f), pendaftarannya dilakukan dengan cara membukukan bidang tanah yang merupakan tanah Negara dalam daftar tanah. Pendaftaran tanah sebagaimana disebutkan pada Pasal 3 bertujuan: memberikan kepastian hukum dan perlindungan hukum kepada pemegang hak atas tanah, satuan rumah susun dan hak-hak lain yang terdaftar agar dengan mudah dapat membuktikan dirinya sebagai pemegang hak yang bersangkutan; (2) menyediakan informasi kepada pihak-pihak yang berkepentingan termasuk pemerintah agar dengan mudah dapat memperoleh data yang diperlukan dalam mengadakan perbuatan hukum mengenai bidang-bidang tanah dan satuan-satuan rumah susun yang sudah terdaftar; (3) terselenggaranya tertib administrasi pertanahan.

Dalam proses pendaftaran, sebagai tanda selesainya pendaftaran hak atas tanah dikeluarkan sertifikat hak atas tanah seperti tercaantum pada Pasal 19 ayat (2) UUPA bahwa pendaftaran tanah meliputi antara lain pada huruf (c) pemberian surat-surat tanda bukti hak, yang berlaku sebagai alat pembuktian yang kuat. Surat tanda bukti hak sebagaimana dimaksud adalah sertifikat sebagaimana tercantum pada Pasal 1 angka (20) PP Pendaftaran Tanah. Menurut Sumardji ${ }^{6}$, sertifikat adalah salinan buku tanah dan surat ukur dan mengandung data fisik dan yuridis mengenai bidang tanah tertentu yang sudah ada haknya menurut UUPA.

Berkaitan dengan proses pendaftaran hak atas tanah yang merupakan kewenangan pemerintah dan dilaksanakan Badan Pertanahan Nasional melalui Kantor Pertanahan Kabupaten atau Kota, maka

${ }^{6}$ Sumardji, Sertifikat Sebagai Alat Bukti Hak Atas Tanah, Yuridika, Vol. 16, No. 1, JanuariPebruari 2001, hlm. 90

Fani Martiawan, Tanggung Gugat Pejabat Tata Usaha Negara Dalam Bentuk Pembatalan Sertipikat Hak Atas Tanah 
Supremasi Hukum Jurnal Penelitian Hukum

p-ISSN: 1693-766X ; e-ISSN: 2579-4663, Vol. 26, No. 2, Agustus 2017

pemberian sertifikat hak atas merupakan suatu keputusan Negara. Oleh karena itu hal ini dapat dikaitkan dengan UndangUndang No. 5 Tahun 1986 Tentang Peradilan Tata Usaha Negara sebagaimana dirubah dengan Undang-Undang No. 51 Tahun 2009 Tentang Perubahan Kedua Undang-Undang no. 5 Tahun 1986 (UU PTUN Kedua). Berdasarkan Pasal 1 angka (8) UU PTUN Kedua dinyatakan bahwa Badan atau Pejabat Tata Usaha Negara adalah badan yang melaksanakan urusan pemerintahan berdasarkan peraturan perundang-undangan yang berlaku. Dalam penjelasan disebutkan bahwa yang dimaksud dengan urusan pemerintahan adalah kegiatan yang bersifat eksekutif.

Ridwan H.R ${ }^{7}$ mengutip pendapat A. D. Belfiante yaitu: Het word bestuur pleggt te worden gelijgesteld met uitvorende macht. Het betekent dan het gedeelte van de

7 Ridwan H.R, Hukum Administrasi Negara, UII Press, Yogyakarta, 2003, hlm. 115. Fani Martiawan, Tanggung Gugat Pejabat Tata Usaha Negara Dalam Bentuk Pembatalan Sertipikat Hak Atas Tanah

overheisorganen en van overheidsfuncties, die niet zijn wetgevende en recht organen en functies. Kata pemerintahan diartikan sama dengan kekuasaan eksekutif. Artinya pemerintahan merupakan bagian dari organ dan fungsi pemerintahan, selain organ dan fungsi pembuat undang-undang dan peradilan. ${ }^{8}$ Selanjutnya Ridwan H.R mengutip pendapat C.J.N Versteden yaitu: ${ }^{9}$ Onder (openbaar) bestuur verstaan wij alle activiteiten van de overhead die niet als wetgiving en rechtspraak zjin aan te merken. ${ }^{10}$ (Pemerintahan umum diartikan semua aktivitas pemerintah, yang tidak termasuk sebagai pembuatan undang-undang dan peradilan.

Beragamnya lembaga atau organ pemerintahan dan yang dipersamakan dengan organ

8 A.D Belifante dan Soetan Batoeah Borhanoedin, Pokok-Pokok Hukum Tata Usaha Negara, Bina Cipta, Jakarta, 1983, hlm. 98.

9 Ridwan H.R, Op. Cit., hlm. 116

10 C.J.N Versteden, Inleiding Algemeen Bestuurecht, Samson H.D. Tjeenk Willing, Alphen aan den Rijn, 1984, hlm. 71. 
Supremasi Hukum Jurnal Penelitian Hukum

p-ISSN: 1693-766X ; e-ISSN: 2579-4663, Vol. 26, No. 2, Agustus 2017

pemerintahan menunjukkan

bahwa pengertian Badan atau

Pejabat TUN memiliki cakupan

yang sangat luas, berarti luas

pula pihak-pihak yang dapat

diberikan

wewenang

pemerintahan untuk membuat

dan mengeluarkan keputusan.

Dengan kata lain setiap badan, organisasi atau perorangan yang mendapat limpahan wewenang untuk menyelenggarakan urusan pemerintahan itu dapat digugat di PTUN atas keputusankeputusannya.

Menurut Indroharto, pengertian Badan atau Pejabat TUN termasuk BUMN, Telkom, PLN, POS, PAM dan sebagainya dapat digugat di PTUN, dengan demikian yang penting bukan penyebutan unsur Badan atau Pejabat TUN tersebut, melainkan unsur menjalankan urusan pemerintahan berdasarkan peraturan perundangundangan ${ }^{11}$ Menurut Diana

\section{Indroharto, Usaha}

Memahami Undang-Undang Tentang Pereadilan Tata Usaha Negara, Buku II, Cet. Kesembilan, Pustaka Sinar Harapan,. Jakarta, 2005, hlm. 106107.

Fani Martiawan, Tanggung Gugat Pejabat Tata Usaha Negara Dalam Bentuk Pembatalan Sertipikat Hak Atas Tanah
Halim Koentjoro, ${ }^{12}$ untuk dapat disebut sebagai badan atau Pejabat Tata Usaha Negara (Pejabat TUN) haruslah memenuhi beberapa unsur, yaitu: (1) Badan atau pejabat; (2) Melaksanakan urusan pemerintahan; (3) Berdasarkan peraturan perundang-undangan; (4) Peraturan perundangundangan yang berlaku.

Berdasarkan pendapat tersebut, maka Badan atau Pejabat TUN adalah apa saja (Badan) dan siapa saja (Orang) berdasarkan peraturan perundang-undangan yang berlaku melaksanakan suatu bidang urusan pemerintahan. Dengan demikian, siapa saja dan apa saja yang melaksanakan fungsi pemerintahan, baik di lingkungan pemerintah (eksekutif), legislatif, yudikatif ataupun seorang swasta atau badan hukum perdata swasta, Badan Usaha Milik Negara (BUMN), Perjan, Persero, Perum, Universitas Swasta, Yayasan,

12 Diana Halim Koentjoro, Hukum Administrasi Negara, Bogor, Ghalia Indonesia, 2004, hlm.25. 
Supremasi Hukum Jurnal Penelitian Hukum

p-ISSN: 1693-766X ; e-ISSN: 2579-4663, Vol. 26, No. 2, Agustus 2017

dan sebagainya, bilamana Jaya, Trikora Lloyd (bidang berdasarkan peraturan perundang-undangan yang berlaku itu melakukan fungsi pemerintahan, maka semuanya adalah Pejabat TUN. Diana Halim Koentjoro menambahkan bahwa dapat disimpulkan, Badan atau Pejabat TUN menurut UU PTUN Kedua adalah: ${ }^{13}$ (1) Instansi resmi pemerintah yang berada di bawah presiden sebagai kepala eksekutif; (2) Instansi dalam lingkungan kekuasaan Negara di luar kekuasaan eksekutif yang berdasarkan peraturan perundang-undangan

melaksanakan suatu urusan pemerintahan; (2) Badan hukum perdata yang didirikan pemerintah dengan maksud untuk melaksanakan tugastugas pemerintahan, seperti: BUMN, PAM, PLN, PT. KAI; (3) Instansi yang merupakan kerjasama antara para pihak pemerintah dengan pihak swasta yang melaksanakan tugas pemerintahan seperti: PT PAM

${ }^{13}$ Ibid, hlm. 27 perdata), PT. Caltex (bidang publik); (4) Lembaga Hukum swasta yang melaksanakan tugas pemerintahan, seperti Perguruan Tinggi Swasta, Rumah Sakit Swasta, Rumah Jompo, Rumah Yatim Piatu, dan lain sebagainya.

Berdasarkan uraian tersebut, maka Badan Pertanahan Nasional adalah termasuk Pejabat TUN yang berwenang untuk mendaftar dan menerbitkan sertifikat hak atas tanah. Berkaitan dengan kewenangan ini, menurut H.D. Stoud dalam bukunya "De Betekenissen Van De Wet" (yang dikutip oleh Irfan Fachruddin ${ }^{14}$ ), kewenangan adalah: Bevoegheid wet kan worden omscrevenals het geheel van bestuurechttelijke bevoegdheden door publiekrechtelijke rechtssubjecten in het bestuurechttelijke rechtsverkeer. (Wewenang dapat dijelaskan sebagai keseluruhan

$14 \quad$ Irfan Fachruddin,
Pengawasan Peradilan Administrasi Terhadap Tindakan Pemerintah, Bandung, Alumni, 2004, hlm. 4.)

Fani Martiawan, Tanggung Gugat Pejabat Tata Usaha Negara Dalam Bentuk Pembatalan Sertipikat Hak Atas Tanah 
Supremasi Hukum Jurnal Penelitian Hukum

p-ISSN: 1693-766X ; e-ISSN: 2579-4663, Vol. 26, No. 2, Agustus 2017

aturan-aturan yang berkenaan dengan perolehan dan penggunaan wewenang pemerintah oleh subjek hukum publik dalam hukum publik). Diana Halim Koentjoro menambahkan, bahwa macammacam kewenangan atau kompetensi administrasi Negara atau Pejabat TUN adalah:15

(1) Atribusi yaitu pemberian kewenangan yang baru kepada Pejabat TUN berdasarkan suatu perundang-undangan formal;

(2) Delegasi yaitu pemindahan atau pengalihan kewenangan yang ada berdaarkan perundangundangan formal;

(3) Mandat, orang yang mendapat bukan karena pengalihan kewenangan, namun karena yang berkompeten berhalangan.

Dalam kaitan dengan konsep atribusi, delegasi, ataupun mandat, J.G. Brouwer dan A.E. Schilder, mengatakan: ${ }^{16}$ (1) With atribution, power is granted to an administrative 28.

15 Diana Halim, Op. Cit., hlm.

16 J.G. Brouwer and Schilder, A Survey of Dutch Administrative Law, Nijmegen, Ars Aeguilibri, 1998, hlm. 16-17.

Fani Martiawan, Tanggung Gugat Pejabat Tata Usaha Negara Dalam Bentuk Pembatalan Sertipikat Hak Atas Tanah authority by an independent legislative body. The power is initial (originair), which is to say that is not derived from a previously existing power. The legislative body creates independent and previously non existent powers and assigns them to an authority; (2) Delegation is a transfer of an acquired atribution of power from one administrative authority to another, so that the delegate (the body that the acquired the power) can exercise power in its own name; (3) With mandate, there is not transfer, but the mandate giver (mandans) assigns power to the body (mandataris) to make decision or take action in its name. J.G. Brouwer berpendapat bahwa atribusi merupakan kewenangan yang diberikan kepada suatu organ (institusi) pemerintahan atau lembaga Negara oleh suatu badan legislatif yang independen. Kewenangan ini adalah asli, yang tidak diambil dari kewenangan yang ada sebelumnya. Badan legislatif menciptakan kewenangan 
mandiri dan bukan perluasan kewenangan sebelumnya dan memberikan kepada organ yang berkompeten.

Sedangkan delegasi adalah kewenangan yang dialihkan dari kewenangan atribusi dari suatu organ (institusi) pemerintahan kepada organ lainnya sehingga delegator (organ yang telah memberi kewenangan) dapat menguji kewenangan tersebut atas namanya. Sedangkan pada mandat, tidak terdapat suatu pemindahan kewenangan tetapi pemberi mandat (mandator) memberikan kewenangan kepada organ lain (mandataris) untuk membuat keputusan atau mengambil suatu tindakan atas namanya.

Kewenangan harus

dilandasi oleh ketentuan hukum yang ada (konstitusi) agar kewenangan tersebut sah. Mendasar pada pendapat diatas, atribusi menunjuk pada kewenangan yang asli atas dasar konstitusi (UUD), lalu kewenangan delegasi harus ditegaskan suatu pelimpahan wewenang kepada organ pemerintahan yang lain dimana yang melimpahkan itu mereka yang mendapatkan kewenangan atribusi dari konstitusi. Pada mandat pelimpahannya diberikan oleh yang menerima kewenangan delegasi, dalam hal mandat ini tidak terjadi pelimpahan apapun dalam arti pemberian wewenang, akan tetapi, yang diberi mandat bertindak atas nama pemberi mandat, dalam pemberian mandat, pejabat yang diberi mandat menunjuk pejabat lain untuk bertindak atas nama mandator (pemberi mandat).

Berdasarkan penjabaran diatas, maka penerbitan sertifikat hak atas tanah oleh Badan Pertanahan Nasional melalui Kantor Pertanahan Kabupaten atau Kota, awal mula kewenangannya adalah kewenangan yang diberikan dengan cara delegasi dari pemerintah kepada Badan Pertanahan Nasional. Berdasarkan Pasal 19 ayat (2) huruf (c), Pasal 23, Pasal 32 dan

Fani Martiawan, Tanggung Gugat Pejabat Tata Usaha Negara Dalam Bentuk Pembatalan Sertipikat Hak Atas Tanah 
Supremasi Hukum Jurnal Penelitian Hukum

p-ISSN: 1693-766X ; e-ISSN: 2579-4663, Vol. 26, No. 2, Agustus 2017

Pasal 38 UUPA jo. Pasal 5 PP Pendaftaran Tanah jo. Pasal 70 ayat (1) Peraturan Menteri Negara Agraria / Kepala Badan Pertanahan Nasional No. 3 Tahun 1997 Tentang Ketentuan Pelaksanaan PP Pendaftaran Tanah, maka dalam hal ini Kepala Kantor Pertanahan Kabupaten atau Kota dan Ketua Panitia Adjudikasi itu memenuhi unsur-unsur Badan atau Pejabat TUN yang ketentuannya terdapat dalam Pasal 1 angka (8) UU PTUN Kedua.

Badan Pertanahan

Nasional merupakan badan yang kewenangannya dilimpahkan secara delegasi oleh pemerintah dan merupakan Pejabat TUN yang berwenang mengeluarkan sertifikat hak atas tanah melalui Kantor Pertanahan Kabupaten / Kota. Dalam hal sebagai Pejabat TUN, menurut Soehino ${ }^{17}$ perbuatan sebagai Pejabat TUN dapat dikelompokkan menjadi 3 (tiga) macam perbuatan-

17 Soehino, Asas-Asas Hukum Tata Usaha Negara, Yogyakarta, Liberty, 1998, hlm. 54.

Fani Martiawan, Tanggung Gugat Pejabat Tata Usaha Negara Dalam Bentuk Pembatalan Sertipikat Hak Atas Tanah perbuatan Tata Usaha Negara, yaitu:

(1) Mengeluarkan atau menetapkan keputusan, yang disebut ketetapan administrasi atau beschikking;

(2) Mengeluarkan peraturan atau regeling;

(3) Melakukan perbuatan materiil atau materiele daad, atau perbuatan wajar.

Pasal 1 angka (3) UU PTUN Kedua menyatakan, bahwa keputusan atau penetapan (beschikking) adalah suatu penetapan tertulis yang dikeluarkan oleh badan atau pejabat Tata Usaha Negara yang berisi tindakan hukum Tata Usaha Negara yang berdasarkan peraturan perundang-undangan yang berlaku, yang bersifat konkrit, individual dan final yang menimbulkan akibat hukum bagi seseorang dan badan hukum perdata. Istilah beschikking sudah sangat tua dan dari segi keabsahan digunakan dalam beberapa arti, meskipun demikian istilah beschikking dalam bahasan ini hanya dibatasi dalam arti yuridis 
Supremasi Hukum Jurnal Penelitian Hukum

p-ISSN: 1693-766X ; e-ISSN: 2579-4663, Vol. 26, No. 2, Agustus 2017

sebagaimana dikatakan D. Van

inhoudende

een

Wijk/Willemkinijnenbelt ${ }^{18}$,

publiekrexhtelijke

bahwa Ketetapan merupakan

rechtshandeling.

Terhadap

keputusan pemerintahan untuk

rumusan Pasal 1.3 AWB

hal yang bersifat konkrit dan

tersebut, Ten Berge

individual (tidak ditujukan

mengungkapkan bahwa terdapat

untuk umum) dan sejak dulu telah dijadikan instrument

yuridis pemerintahan yang

utama.

Menurut P. De Haan ${ }^{19}$ mengenai beshikking yaitu: De administratieve beschikking is de meest voorkomende en ook meest bestudeerde bestuurshandeling. (Ketetapan administrasi merupakan bagian dari tindakan pemerintahan yang paling banyak muncul dan paling banyak dipelajari. (terjemahan penulis). Berdasarkan Pasal 1.3.

Algemene Wet Bestuursrecht (AWB) ditentukan sebagai berikut: Een schriftelijke beslissing van bestuurorgaan,

18D. Van

Wijk/Willemkinijnenbelt,

Hoofdstukken van Administratief

Recht, Zasde Druk, Vuga, 1968, hlm.202.

19 P. De Haan, et, al, Bestuursrecht In De Sociale Rechtstaat, Deel 1, Ontwikkeling, Organisatie, Instrumentarium, Kuwer-Deventer, 1986, hlm. 17. $\begin{array}{ll}\text { Kuwer-Deventer, 1986, hlm. } 17 . & { }^{21} \text { Soehino, Op. Cit., hlm. } 56 .\end{array}$ Pembatalan Sertipikat Hak Atas Tanah ditunjukkan pada isi atau substansi dari keputusan

20 Ten Berge, Bescherming Tegen de Overheid, Derde Druk, W.e.J. Tjenk Willink, Zwolle, Nederlands, 1995, hlm. 138. 21 Soehino, Op. Cit., hlm. 56.
Usaha Negara Dalam Bentuk

tiga unsur penting dari besluit, yaitu schriftelijke beslissing van een rechtshandeling (tindakan hukum dalam bentuk keputusan pemerintahan tertulis); wilsuiting/wilsvorming (pembentukan kehendak/pernyataan kehendak); dan publiekrechtelijk (tindakan hukum publik). ${ }^{20}$

Berdasarkan Pasal 1 angka (9) UU PTUN Kedua, suatu keputusan dapat dikategorikan menjadi Keputusan Tata Usaha Negara (KTUN) dengan memenuhi unsur-unsur sebagai berikut:21 (1) Penetapan Tertulis, syarat tertulis dari suatu penetapan tidak ditujukan pada bentuk formalnya, tetapi 
Supremasi Hukum Jurnal Penelitian Hukum

p-ISSN: 1693-766X ; e-ISSN: 2579-4663, Vol. 26, No. 2, Agustus 2017

tersebut. Persyaratan tertulis ini dimaksudkan untuk mempermudah dalam pembuktian apabila terjadi sengketa antara pemerintah dengan rakyatnya sebagai akibat dikeluarkannya

suatu

keputusan; (2). Dikeluarkan oleh Badan atau Pejabat TUN, adalah badan atau pejabat di pusat dan daerah yang melaksanakan kegiatan yang bersifat eksekutif seperti yang dimaksud dalam UU PTUN; (3). Berisi Tindakan Hukum Tata Usaha Negara, yaitu perbuatan hukum Badan atau Pejabat TUN yang bersumber pada suatau ketentuan hukum Tata Usaha Negara yang dapat menumbulkan hak dan kewajiban kepada orang lain; (4). Berdasarkan Peraturan Perundang-undangan yang berlaku, artinya bahwa keputusan itu harus didasarkan pada kewenangan dari pejabat tersebut, bersumber pada peraturan perundang-undangan yang berlaku atau dengan kata lain bahwa keputusan itu berfungsi untuk melaksanakan peraturan yang bersifat umum, jadi harus ada peraturan yang menjadi dasarnya; (5). Bersifat konkrit, individual dan final. (6). Menimbulkan akibat hukum bagi seseorang atau badan hukum perdata, yaitu menimbulkan hak dan kewajiban kepada seseorang atau badan hukum perdata yang terkena keputusan tersebut.

Soehiono menambahkan, ketetapan administrasi itu berbentuk khusus, yaitu:22 (a) Ijin; (b) Dispensasi; (c) Konsesi. Pada hakikatnya dispensasi itu adalah suatu koreksi alat-alat perlengkapan administrasi Negara terhadap suatu undangundang. Ijin dan konsesi, pada hakikatnya hanyalah merupakan pelaksanaan saja suatu aturan hukum, dalam hal-hal konkrit. Perbedaan ijin dan konsesi hanya bersifat relatif . Ijin pada umumnya diberikan dalam usaha-usaha kecil dan hanya menyangkut perorangan, sedangkan konsesi diberikan

22 Ibid, h. 61.

Fani Martiawan, Tanggung Gugat Pejabat Tata Usaha Negara Dalam Bentuk Pembatalan Sertipikat Hak Atas Tanah 
Supremasi Hukum Jurnal Penelitian Hukum

p-ISSN: 1693-766X ; e-ISSN: 2579-4663, Vol. 26, No. 2, Agustus 2017

dalam usaha-usaha besar dan berkaitan dengan kepentingan banyak orang. Dengan demikian maka hanya ada dua macam lembaga hukum saja sebagai jenis khusus ketetapan administrasi, yaitu ijin dan konsesi, karena dispensasi pada asasnya merupakan perbuatan alat perlengkapan administrasi Negara yang memuat suatu koreksi atas suatu undangundang.

Dengan uraian tersebut, maka Badan Pertanahan Nasional merupakan Pejabat TUN, mendapat limpahan wewenang secara delegasi oleh pemerintah, untuk dapat mengurus pendaftaran tanah yang berujung dengan dikeluarkannya sertipikat hak atas tanah melalui Kantor Pertanahan Kabupaten / Kota. Sertifikat tersebut tergolong (karena memenuhi syarat) sebagai KTUN yang merupakan penetapan tertulis, berbentuk ijin $^{23}$, bersifat konkrit, individual

23 Diana Halim Koentjoro, $O p$. Cit., hlm. 65-66; Menurut Prins, ijin adalah ketetapan yang ditujukan

Fani Martiawan, Tanggung Gugat Pejabat Tata Usaha Negara Dalam Bentuk Pembatalan Sertipikat Hak Atas Tanah

dan final, dan timbulnya sertifikat ini menimbulkan hak dan kewajiban bagi pemegang hak maupun kepada orang lain secara tidak langsung, dan dikeluarkan berdasarkan peraturan perundang-undangan yang berlaku.

\section{Pembatalan Sertipikat Hak} Atas Tanah

Sertipikat sebagai tanda bukti hak, bila dikaitkan dengan sistem publikasi di Indonesia, maka menganut sistem publikasi negatif yang mengarah kepada publikasi positif, dimana pemegang sertifikat dianggap sebagai pemilik hak atas tanah. Mengenai kekuatan hukum sertipikat sebagai tanda bukti hak, ketentuan Pasal 32 PP Pendaftaran Tanah menyatakan bahwa sertipikat merupakan surat tanda bukti hak yang berlaku sebagai alat pembuktian yang kuat mengenai data fisik dan data yuridis yang termuat didalamnya, sepanjang data fisik

kepada suatu obyek yang tidak dilarang dan hal yang tidak diijinkan adalah terbatas. 
Supremasi Hukum Jurnal Penelitian Hukum

p-ISSN: 1693-766X ; e-ISSN: 2579-4663, Vol. 26, No. 2, Agustus 2017

dan data yuridis tersebut sesuai dengan data yang ada dalam surat ukur dan buku tanah hak yang bersangkutan.

Dalam hak atas suatu bidang tanah sudah diterbitkan sertifikat secara sah atas nama seseorang atau badan hukum, yang memperoleh tanah tersebut dengan itikad baik dan secara nyata menguasainya, maka pihak lain yang merasa mempunyai hak atas tanah itu tidak dapat lagi menuntut pelaksanaan hak tersebut apabila dalam waktu 5 (lima) tahun sejak diterbitkannya sertifikat tidak mengajukan keberatan secara tertulis kepada pemegang sertifikat dan/atau Kepala Kantor Pertanahan Kabupaten/Kota yang bersangkutan ataupun tidak mengajukan gugatan ke pengadilan mengenai penguasaan tanah atau penerbitan sertifikat tersebut.

Dalam Peraturan Menteri Agraria / Kepala BPN No. 3 Tahun 1999, Pasal 1 angka (12) menyatakan mengenai rumusan pembatalan hak atas tanah, adalah : Pembatalan keputusan mengenai suatu hak atas tanah karena keputusan tersebut mengandung cacat hukum dalam penerbitannya atau melaksanakan putusan pengadilan yang telah berkekuatan hukum tetap. Sedangkan Pasal 1 angka (14) Peraturan Menteri Agraria / Kepala BPN No. 9 Tahun 1999, pengertian pembatalan hak atas tanah adalah pembatalan keputusan pemberian hak atas tanah atau sertifikat hak atas tanah karena keputusan tersebut mengancung cacat hukum administrasi dalam penerbitannya, atau melaksanakan putusan pengadilan yang telah mempunyai kekuatan hukum tetap.

Berdasarkan kedua peraturan tersebut Hasan Basri memberikan penjelasan perbandingan bahwa, definisi yang ada dalam Pasal 1 angka (14) Peraturan Menteri Agraria / Kepala BPN No. 9 Tahun 1999 
Supremasi Hukum Jurnal Penelitian Hukum

p-ISSN: 1693-766X ; e-ISSN: 2579-4663, Vol. 26, No. 2, Agustus 2017

itu definisinya lebih luas dan tegas dari rumusan yang disebutkan dalam Pasal 1 angka (12) Peraturan Menteri Agraria / Kepala BPN No. 3 Tahun 1999. Hal ini dikarenakan menurut Pasal 1 angka (14) Peraturan Menteri Agraria / Kepala BPN No. 9 Tahun 1999 itu pembatalan tidak saja dapat dilakukan terhadap keputusan pemberian hak atas tanah, tetapi juga dapat dilakukan terhadap sertifikat hak atas tanah, meskipun dengan batalnya keputusan pemberian hak atas tanah maka sertifikat hak atas tanah serta merta menjadi batal juga.

Dalam Pasal 106 Peraturan Menteri Agraria / Kepala BPN No. 9 Tahun 1999 dinyatakan bahwa keputusan pembatalan hak atas tanah karena cacat hukum administratif dalam penerbitannya, dapat dilakukan karena permohonan yang berkepentingan atau oleh pejabat yang berwenang tanpa permohonan. Permohonan pembatalan hak dapat diajukan langsung kepada Menteri atau pejabat yang ditunjuk atau melalui Kepala Kantor $\begin{array}{lll}\text { Pertanahan. } & \text { Pasal } 107\end{array}$ Peraturan Menteri Agraria/Kepala BPN No. 9 Tahun 1999 menyatakan bahwa cacat hukum administratif adalah:

a) Kesalahan prosedur;

b) Kesalahan penerapan peraturan perundangundangan;

c) Kesalahan subjek hak;

d) (d) Kesalahan objek hak;

e) Kesalahan jenis hak;

f) Kesalahan perhitungan luas;

g) Terdapat tumpang tindih hak atas tanah;

h) Data yuridis atau data fisik tidak benar;

i) Kesalahan lainnya yang bersifat hukum administratif.

Dari uraian tersebut, maka dapat dikatakan bahwa konsekuensi yuridis atas sertifikat yang tidak memenuhi syarat administratif adalah pembatalan sertifikat yang bersangkutan.

Berdasarkan telaah sebelumnya, diketahui bahwa sertifikat hak atas tanah merupakan KTUN, dan merupakan suatu penetapan tertulis. Penetapan tertulis 
Supremasi Hukum Jurnal Penelitian Hukum

p-ISSN: 1693-766X ; e-ISSN: 2579-4663, Vol. 26, No. 2, Agustus 2017

diatur dalam Pasal 1 angka (3) Undang-Undang No. 9 Tahun 2004 Tentang Perubahan Pertama Undang-Undang No. 5 Tahun 1986 Tentang Peradilan Tata Usaha Negara (UU PTUN Pertama). Penjelasan Pasal 1 angka (3) disebutkan bahwa istilah penetapan tertulis terutama menunjuk kepada isi dan bukan kepada bentuk keputusan yang dikeluarkan oleh Badan atau Pejabat TUN. Keputusan ini memang diharuskan tertulis, namun yang disyaratkan tertulis bukanlah bentuk formatnya seperti surat keputusan pengangkatan dan sebagainya. Persyaratan tertulis itu diharuskan untuk kemudahan pembuktian, oleh karena itu sebuah memo atau nota dapat memenuhi syarat tertulis tersebut dan akan merupakan suatu keputusan Badan atau Pejabat TUN menurut Undang-Undang ini apabila sudah jelas: (1) Badan atau Pejabat TUN mana yang mengeluarkannya; (2) Maksud serta mengenai hal apa tulisan itu; (3) Kepada siapa tulisan itu ditujukan dan apa yang ditetapkan didalamnya.

Mengacu

ketentuan tersebut, Irawan Soerojo mengatakan bahwa hal ini berarti sertifikat tanah merupakan refleksi dari suatu penetapan tertulis sehingga setiap adanya gugatan yang berhubungan dengan sertifikat tanah menjadi kompetensi Peradilan Tata Usaha Negara. ${ }^{24}$ Berdasarkan Pasal 53 ayat (1) UU PTUN Pertama, diatur alasan-alasan yang dapat digunakan mengajukan gugatan tidak sah-nya keputusan, yaitu: (1) Keputusan Tata Usaha Negara yang digugat itu bertentangan dengan peraturan perundang-undangan yang berlaku; (2) Keputusan Tata Usaha Negara yang digugat ini bertentangan dengan asas umum pemerintahan yang baik.

Serifikat hak atas tanah adalah produk pemerintah yang

24 Irawan Soerodjo, Kepastian Hukum Hak Atas Tanah di Indonesia, Surabaya, Arkola, 2003, hlm. 206-207.

Fani Martiawan, Tanggung Gugat Pejabat Tata Usaha Negara Dalam Bentuk Pembatalan Sertipikat Hak Atas Tanah 
lahir karena hukum, sifatnya konkret karena ditujukan untuk subyek dan obyek yang dapat ditentukan. Sertifikat hak atas tanah juga bersifat individual dan final karena tidak ditujukan untuk umum akan tetapi hanya bagi yang tercantum dalam sertifikat tersebut serta tidak memerlukan persetujuan instansi lain. Bila dilihat dari tindakan pemerintah dalam kegiatan pemberian sertifikat hak atas tanah bertujuan untuk menimbulkan keadaan hukum baru sehingga lahir pula hakhak dan kewajiban-kewajiban hukum baru terhadap orang/badan hukum tertentu.

Berdasarkan penjabaran sebelumnya, diketahui bahwa sertifikat hak atas tanah itu bersifat konkret, individual dan final. Bersifat konkret maksudnya obyek yang diputuskan dalam KTUN itu tidaklah abstrak, namun berwujud, tertentu atau dapat ditentukan. Individual maksudnya KTUN itu tidak akibat yang ditimbulkan, maka

ditujukan untuk umum, melainkan tertentu, baik alamat maupun hak yang dituju. Final maksudnya akibat hukum yang ditimbulkan serta mengeluarkan penetapan tertulis itu harus benar-benar sudah merupakan akibat hukum yang definitif. Menimbulkan akibat hukum maksudnya menimbulkan suatu perubahan dalam suasana hubungan hukum yang telah ada, karena penetapan tertulis merupakan suatu tindakan hukum. Demikian juga sebagai suatu tindakan dimaksudkan untuk menimbulkan suatu akibat hukum. Oleh karena itu bila KTUN tersebut sampai menimbulkan akibat hukum bagi seseorang atau badan hukum berupa kerugian, maka yang terjadi adalah sengketa tata usaha negara (Sengketa TUN) ${ }^{25}$.

Berdasarkan Pasal 1 angka (4) dan (5) UU PTUN Pertama, dijabarkan bahwa Sengketa TUN

25 Indroharto, Usaha Memahami Undang-Undang Tentang Peradilan Tata Usaha Negara, Buku I, Beberapa Pengertian Dasar Hukum Tata Usaha Negara, Pustaka Sinar Harapan, Jakarta, 1996, hlm. 163.

Fani Martiawan, Tanggung Gugat Pejabat Tata Usaha Negara Dalam Bentuk Pembatalan Sertipikat Hak Atas Tanah 
Supremasi Hukum Jurnal Penelitian Hukum

p-ISSN: 1693-766X ; e-ISSN: 2579-4663, Vol. 26, No. 2, Agustus 2017

adalah sengketa yang timbul di bidang Tata Usaha Negara antara orang atau badan hukum perdata dengan Badan atau maupun di daerah, sebagai akibat dikeluarkannya KTUN. Dalam hal ini termasuk sengketa kepegawaian berdasarkan peraturan perundang-undangan yang berlaku. Dengan adanya sengketa tersebut, pihak yang dirugikan dapat menggugat, dengan mengajukan permohonan yang berisi tuntutan terhadap Badan atau Pejabat TUN dan diajukan ke pengadilan untuk mendapatkan keputusan. Termasuk sebagai suatu keputusan Badan atau Pejabat TUN yang dapat bilamana Badan atau Pejabat TUN tidak mengeluarkan keputusan, sedangkan hal itu menjadi kewajibannya, maka hal tersebut dapat disamakan dengan KTUN. Jika suatu Badan atau Pejabat TUN tidak mengeluarkan keputusan yang dimohonkan, sedangkan jangka Pejabat TUN, baik di pusat dijadikan sengketa TUN

waktu sebagaimana ditentukan dalam peraturan perundangundangan dimaksud telah lewat, maka Badan atau Pejabat TUN tersebut dianggap telah menolak mengeluarkan keputusan yang dimaksud. ${ }^{26}$.

Berdasarkan Pasal 53 ayat (2) UU PTUN Pertama, untuk dapat diajukan ke pengadilan, KTUN tersebut haruslah bertentangan dengan peraturan perundang-undangan yang berlaku dan bertentangan dengan asas-asas umum pemerintahan yang baik. Keputusan Badan atau Pejabat TUN itu bertentangan dengan peraturan perundang-undangan yang berlaku apabila keputusan yang bersangkutan dengan ketentuan-ketentuan dalam peraturan perundang-undangan yang bersifat prosedural atau formal, atau bertentangan dengan ketentuan-ketentuan dalam peraturan perundangundangan yang bersifat materiil/ substansial, dan dikeluarkan oleh Badan atau Pejabat TUN 165

26 Indroharto, Op. Cit., hlm.

Fani Martiawan, Tanggung Gugat Pejabat Tata Usaha Negara Dalam Bentuk Pembatalan Sertipikat Hak Atas Tanah 
Supremasi Hukum Jurnal Penelitian Hukum

p-ISSN: 1693-766X ; e-ISSN: 2579-4663, Vol. 26, No. 2, Agustus 2017

yang tidak berwenang. Pengajuan gugatan atas sengketa TUN ini diajukan kepada Pengadilan Tata Usaha Negara, berdasarkan Pasal 47 dan 49 UU PTUN Pertama, disebutkan bahwa Pengadilan Tata Usaha Negara bertugas dan berwenang memeriksa, memutus dan menyelesaikan sengketa TUN. Pengadilan Tata Usaha Negara tidak mempunyai kewenangan untuk memeriksa sengketa Tata Usaha Negara jika keputusan dikeluarkan dalam waktu perang, keadaan bahaya, keadaan bencana alam, atau keadaan luar biasa yang membahayakan berdasarkan peraturan perundang-undangan yang berlaku, dalam keadaan mendesak untuk kepentingan umum berdasarkan peraturan perundang-undangan yang berlaku.

Dengan demikian sertifikat yang dikeluarkan oleh BPN melalui Kantor Pertanahan Kota/Kabupaten merupakan KTUN. Bila sertifikat itu terdapat cacat administratif atau juga merugikan pihak lain, maka dapat menimbulkan sengketa TUN. Gugatannya terhadap sengketa TUN ini diajukan kepada Pengadilan Tata Usaha Negara untuk dapat dibatalkan sertifikatnya. Berkaitan dengan ini, sebenarnya ada upaya yang dapat ditempuh pihak yang mau menggugat, sebagaimana tercermin dalam Pasal 3 UU PTUN Pertama, yaitu:

(1) Apabila Badan atau Pejabat TUN tidak mengeluarkan keputusan sedangkan hal itu menjadi kewajibannya, maka hak tersebut disamakan dengan KTUN;

(2) Jika suatu Badan atau Pejabat TUN tidak mengeluarkan keputusan yang dimohonkan, sedangkan jangka waktu sebagaimana telah lewat, maka Badan atau Pejabat TUN tersebut dianggap telah menolak mengeluarkan keputusan yang dimaksud;

(3) Dalam hal peraturan perundang-undangan yang bersangkutan itu tidak menentukan jangka waktu sebagaimana dimaksud dalam ayat (2), maka setelah lewat jangka waktu 4 (empat) bulan sejak diterimanya permohonan, Badan atau Pejabat TUN yang bersangkutan dianggap telah mengeluarkan keputusan penolakan.

Fani Martiawan, Tanggung Gugat Pejabat Tata Usaha Negara Dalam Bentuk Pembatalan Sertipikat Hak Atas Tanah 


Hakikat peraturan diatas
pada dasarnya setiap Badan
atau Pejabat TUN itu wajib
melayani setiap permohonan
warga masyarakat yang diterima
apabila hal yang dimohonkan
kepadanya itu menurut
peraturan

kewajibannya. Bila terjadi kelalaian terhadap hal tersebut maka walaupun ia tidak berbuat apa-apa terhadap permohonan yang diterimanya itu, UndangUndang menganggap Badan atau Pejabat TUN itu telah menolak permohonan tersebut. Hal ini berarti keputusan ini bersifat fiktif dan negative, karena Badan atau Pejabat TUN yang menerima permohonan itu bersikap diam dan tidak berbuat apa-apa dan tidak mengeluarkan suatu keputusan apapun, tetapi oleh Undang-Undang dianggap telah mengeluarkan suatu penetapan tertulis yang berisi suatu penolakan atas suatu permohonan yang telah diterimanya itu. Dari sini dapat terlihat bila dikaitkan kepada pembahasan sebelumnya, bahwa Fani Martiawan, Tanggung Gugat Pejabat Tata Usaha Negara Dalam Bentuk Pembatalan Sertipikat Hak Atas Tanah

pihak yang mau menggugat itu bisa juga lebih dahulu menggugat Badan Pertanahan Nasional yang merupakan Badan atau Pejabat TUN. Namun bila tidak ada tanggapan tentang pembatalan hak atas tanah, maka dianggap Badan Pertanahan Nasional sudah mengeluarkan penetapan tertulis, yang merupakan KTUN. Oleh karena itu kemudian pihak yang menggugat bisa menggugat KTUN yang baru itu (penolakan dari Badan Pertanahan Nasional) kepada Pengadilan Tata Usaha Negara atas dasar Kantor Pertanahan yang menerbitkan sertifikat padahal tidak memenuhi syarat adminsitrasi, dan karenanya dapat dikatakan telah melakukan perbuatan yang seharusnya tidak menerbitkan sertifikat yang berarti telah menggunakan wewenang melampaui kewenangannya. 
Supremasi Hukum Jurnal Penelitian Hukum

p-ISSN: 1693-766X ; e-ISSN: 2579-4663, Vol. 26, No. 2, Agustus 2017

Implikasi

Pembatalan

Sertipikat Bila Obyek Sedang Dijaminkan

Berkaitan dengan tanah sebagai obyek jaminan, merupakan obyek lembaga jaminan yaitu jaminan dengan Hak Tanggungan. Obyek utama jaminan hak tanggungan adalah hak atas tanah, walaupun dalam praktiknya, seperti dalam Penjelasan Umum UUHT angka (6) ditentukan bahwa dalam kenyataannya seringkali terdapat benda-benda berupa bangunan, tanaman dan hasil karya yang secara tetap merupakan satu kesatuan dengan tanah yang dijadikan jaminan tersebut. Menurut Muhammad Djumhana, Hak Tanggungan mempunyai karakteristik dengan ciri-ciri antara lain:27

(1) Tidak dapat dibagi-bagi kecuali diperjanjikan lain. Maksudnya bahwa Hak Tanggungan membebani secara utuh obyek Hak Tanggungan dan setiap

27 Muhammad Djumhana, Hukum Perbankan di Indonesia, Bandung, Citra Aditya Bakti, 2000, hlm. 411-412.

Fani Martiawan, Tanggung Gugat Pejabat Tata Usaha Negara Dalam Bentuk Pembatalan Sertipikat Hak Atas Tanah bagian darinya, artinya dengan telah dilunasinya sebagian dari hutang yang dijamin itu tidak berarti terbebasnya sebagian obyek Hak Tanggungan dari beban Hak Tanggungan, melainkan Hak Tanggungan itu tetap membebani seluruh obyek Hak Tanggungan untuk sisa hutang yang belum dilunasi. (Pasal 2 pyat (1) UUHT), namun demikian dapat disimpangi artinya Hak Tanggungan itu dapat hanya membebani sisa obyek Hak Tanggungan untuk menjamin sisa hutang yang belum dilunasi apabila diperjanjikan lain (Pasal 2 ayat (2) UUHT);

(2) Tetap mengikuti obyeknya dalam tangan siapapun obyek tersebut berada (droit de suite), maksudnya walaupun obyek Hak Tanggungan sudah berpindah tangan dan menjadi milik pihak lain, kreditor masih tetap dapat menggunakan haknya melakukan eksekusi jika debitor wanprestasi (Pasal 7 UUHT);

(3) Accesoir, artinya merupakan ikutan dari perjanjian pokok, maksudnya bahwa perjanjian Hak Tanggungan tersebut ada apabila telah ada perjanjian pokoknya yang berupa perjanjian yang ditimbulkan hubungan hukum hutang piutang, sehingga akan hapus dengan hapusnya perjanjian pokoknya (Pasal 10 ayat (1) UUHT); 
Supremasi Hukum Jurnal Penelitian Hukum

p-ISSN: 1693-766X ; e-ISSN: 2579-4663, Vol. 26, No. 2, Agustus 2017

(4). Asas spesialitas, yaitu bahwa unsur-unsur Hak Tanggungan tersebut wajib ada untuk sahnya APHT, misalnya mengenai obyek hutang yang dijamin (Pasal 11 ayat (1) UUHT), dan apabila tidak dicantumkan maka mengakibatkan akta yang bersangkutan batal demi hukum;

(5) Asas publisitas, yaitu perlunya perbuatan yang berkaitan dengan Hak Tanggungan ini diketahui pula oleh pihak ketiga, dan salah satu realisasinya yaitu dengan didaftarkannya pemberian Hak Tanggungan tersebut, hal ini merupakan syarat mutlak untuk lahirnya Hak Tanggungan tersebut dan mengikatnya Hak Tanggungan terhadap pihak ketiga (Pasal 13 ayat (1) UUHT).

Berkaitan

dengan

hilangnya hak atas tanah, maka berdampak pula dengan hapusnya Hak Tanggungan. Hal ini diatur dalam Pasal 18 ayat (1) UUHT, yang menegaskan bahwa Hak Tanggungan hapus karena hal-hal sebagai berikut:

(1) Hapusnya utang yang dijamin dengan Hak

Tanggungan;

(2) Dilepaskannya Hak Tanggungan oleh pemegang Hak Tanggungan;

(3) Pembersihan Hak Tanggungan berdasarkan penetapan peringkat oleh Ketua Pengadilan Negeri;

(4) Hapusnya hak atas tanah yang dibebani Hak Tanggungan.

Terlihat dari Pasal 18 ayat (1) angka (4) UUHT, bahwa Hak Tanggungan menjadi hapus bila hak atas tanah yang dibebani Hak Tanggungan hapus. Hal ini cukup dapat dimengerti karena berdasarkan uraian sebelumnya diketahui bahwa Hak Tanggungan adalah hak kebendaan. Bila obyek hak kebendaan itu hilang maka jaminan hak kebendaan itupun tidak ada artinya lagi. Hapusnya hak atas tanah kerapkali terjadi karena lewatnya waktu hak itu diberikan. Hak-hak yang lebih rendah tingkatannya daripada Hak Milik seperti Hak Guna Bangunan atau Hak Guna Usaha dan Hak Pakai, terbatas masa berlakunya, sekalipun fisik tanah tersebut masih nyata ada. Dengan berakhirnya hak atas, maka hak atas tanah yang bersangkutan kembali kepada pemiliknya dan kalau hak tersebut diberikan oleh Negara

Fani Martiawan, Tanggung Gugat Pejabat Tata Usaha Negara Dalam Bentuk Pembatalan Sertipikat Hak Atas Tanah 
Supremasi Hukum Jurnal Penelitian Hukum

p-ISSN: 1693-766X ; e-ISSN: 2579-4663, Vol. 26, No. 2, Agustus 2017

maka tanah tersebut kembali kepada kekuasaan Negara.

Hapusnya pembebanan

hak atas tanah meskipun sertipikat Hak Tanggungan diterbitkan oleh Badan Pertanahan Nasional sebagai badan atau pejabat Tata Usaha Negara yang tergolong sebagai KTUN, jika sertifikat hak atas tanah itu dibatalkan atas putusan Pengadilan Tata Usaha Negara, sertipikat Hak Tanggungan tidak perlu dimohonkan pembatalan, melainkan akan batal dengan sendirinya. Hal ini berarti bahwa dengan dibatalkannya sertipikat hak atas tanah, maka sertipikat Hak Tanggungan menjadi batal. Dengan kata lain tidak perlu dimohonkan pada Pengadilan Tata Usaha Negara, melainkan batal dengan sendirinya atau cukup dimohonkan pembatalan pada BPN. Dan bila sertipikat dibatalkan, maka sesuai Pasal 18 UUHT akan diikuti dengan hapusnya Hak Tanggungan.

\section{SIMPULAN}

Penguasaan tanah sebagai benda tetap membutuhkan pendaftaran hak atas tanah yang akan berujung pada dikeluarkannya sertipikat hak atas tanah. Pendaftaran hak atas tanah dilakukan oleh Badan Pertanahan Nasional melalui Kantor Pertanahan Kabupaten/ Kota yang merupakan Badan atau Pejabat TUN. Sertipikat yang dikeluarkan oleh badan atau Pejabat TUN tergolong sebagai Keputusan Tata Usaha Negara. Bila sertipikat itu ternyata mengandung cacat administartif atau merugikan pihak lain, maka sertipikat dapat digugat pembatalannya dan gugatan pembatalan ini tergolong sebagai sengketa TUN karena yang disengketakan adalah KTUN. Oleh karena itu permohonan gugatan pembatalan dapat diajukan ke Badan atau Pejabat TUN yang mengeluarkan sertipikat, atau kepada Pengadilan Tata Usaha Negara. Implikasinya bila sertipikat hak atas tanah

Fani Martiawan, Tanggung Gugat Pejabat Tata Usaha Negara Dalam Bentuk Pembatalan Sertipikat Hak Atas Tanah 
Supremasi Hukum Jurnal Penelitian Hukum

p-ISSN: 1693-766X ; e-ISSN: 2579-4663, Vol. 26, No. 2, Agustus 2017

dibatalkan sementara tanah sedang dijaminkan, maka jaminan hak atas tanah yang berupa Hak Tanggungan secara otomatis menjadi hapus seketika setelah dikeluarkannya keputusan pembatalan sertipikat hak atas tanah tersebut. Hal ini karena sertipikat hak atas tanah adalah suatu penetapan tertulis yang ditujukan memberikan kepastian hukum, yang

\section{DAFTAR PUSTAKA}

Algemene Wet Bestuursrecht (AWB)

Belfiante, A.D. dan Soetan Batoeah Boerhanudin, 1983, Pokok-Pokok Hukum Tata Usaha Negara, Jakarta: Bina Cipta.

Brouwer, J.G., and Schilder, 1998, Survey of Dutch Administrative Law, Nijmegen, Ars Aeguilibri.

Berge, Ten, J.B.J.M., 1995, Bescherming Tegen de Overheid, Derde Druk, W.e.J Tjeenk Willink, Zwolle, Nederlands.

Budiono, Herlin, 2010, Kumpulan Tulisan Hukum Perdata Di Bidang Kenotariatan, Buku Kedua, Bandung: Citra AdityaBakti. mempunyai sifat sebagai KTUN berbentuk ijin, konkrit, individual dan final. Adanya sertipikat ini menimbulkan hak dan kewajiban bagi pemegang hak maupun kepada orang lain secara tidak langsung, dan dikeluarkan berdasarkan peraturan perundang-undangan yang berlaku.

Chambell Black, Henry, Bryan A. Garner, 2010, Black's Law Dictionary, 9th Edition.

De Haan P, et, al,1986, Bestuursrecht In De Sociale Rechstaat, Deel 1, Ontwikeling Organisatie, Instrumentarium, KuwerDeventer.

Djumhana, Muhammad, 2000, Hukum Perbankan di Indonesia, Bandung, Citra Aditya Bakti.

Fachruddin, Irfan, 2004, Pengawasan Peradilan Administrasi Terhadap Tindakan Pemerintah, Bandung: Alumni.

Indroharto, 1996, Usaha Memahami Undang-Undang Tentang Peradilan Tata Usaha Negara, Buku I, Beberapa Pengertian Dasar

Fani Martiawan, Tanggung Gugat Pejabat Tata Usaha Negara Dalam Bentuk Pembatalan Sertipikat Hak Atas Tanah 
Supremasi Hukum Jurnal Penelitian Hukum

p-ISSN: 1693-766X ; e-ISSN: 2579-4663, Vol. 26, No. 2, Agustus 2017

Hukum Tata Usaha Negara, Jakarta: Pustaka Sinar Harapan.

2005, Usaha

Memahami Undang-Undang Tentang Peradilan Tata Usaha Negara, Buku II, , Jakarta: Pustaka Sinar Harapan, Cet. Kesembilan.

Koentjoro, Diana Halim, 2004, Hukum Administrasi Negara, Bogor: Ghalia Indonesia.

Mertokusumo, Sudikno, 2008, Mengenal Hukum, (Suatu Pengantar), Yogyakarta: Liberty, Edisi Kelima, Cetakan Keempat.

Peraturan Pemerintah No. 40 Tahun 1996 tentang Hak Guna Usaha, Hak Guna Bangunan dan Hak Pakai atas Tanah

Peraturan Pemerintah No. 24 Tahun $1997 \quad$ Tentang Pendaftaran Tanah

Ridwan H.R, 2003, Hukum Administrasi Negara, Yogyakarta, UII Press.

Sumardji, 2001, Sertifikat Sebagai Alat Bukti Hak Atas Tanah, Yuridika, Vol. 16, No. 1, Januari-Pebruari.

Soehino, 1998, Asas-Asas Hukum Tata Usaha Negara, Liberty, Yogyakarta.

Soerodjo, Irawan, Kepastian Hukum Hak Atas Tanah di
Indonesia,

Arkola, Surabaya, 2003.

Subekti, R; Tjitrosudibio, 1980, Kitab Undang-Undang Hukum Perdata (Burgerlijk Wetboek), Jakarta: Pradnya Paramita.

Undang-Undang No. 5 Tahun 1960 tentang Pokok-Pokok Agraria

Undang-Undang No. 5 Tahun 1986 Tentang Peradilan Tata Usaha Negara

Undang-Undang No. 9 Tahun 2004 Tentang Perubahan Pertama Undang-Undang No. 5 Tahun 1986 Tentang Peradilan Tata Usaha Negara

Undang-Undang No. 51 Tahun 2009 Tentang Perubahan Kedua Undang-Undang No. 5 Tahun 1986 Tentang Peradilan Tata Usaha Negara

Undang-Undang No. 4 Tahun 1999 tentang Hak Tanggungan

Wijk, H.D., van, dan Konijnenbellt, Willem, 1968, Hoofdstukken van Administratief Recht, Zade Druk, Vuga.

Versteden, C.J.N, Inleiding Algemeen Bestuurrecht, Samson H.D. Tjeenk Willing, Alphen aan den Rijn, 1984. 
Supremasi Hukum Jurnal Penelitian Hukum

p-ISSN: 1693-766X ; e-ISSN: 2579-4663, Vol. 26, No. 2, Agustus 2017

Zaidun, Muchammad, 2006,

Indonesia, Kapita Selekta

Tantangan Dan Kendala

Penegakan Hukum di

Kepastian Hukum Di

Indonesia, Jakarta: $\mathrm{P}$

Fani Martiawan, Tanggung Gugat Pejabat Tata Usaha Negara Dalam Bentuk Pembatalan Sertipikat Hak Atas Tanah 
Supremasi Hukum : Jurnal Penelitian Hukum

p-ISSN: 1693-766X ; e-ISSN: 2579-4663, Vol. 26, No. 2, Agustus 2017 